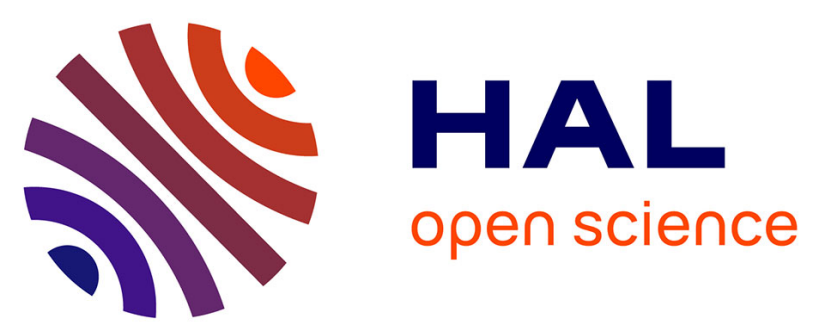

\title{
Temperature Dependent 4-, 5- and 6-Fold Coordination of Aluminum in MOCVD-Grown Amorphous Alumina Films: From Local Coordination to Material Properties
}

Alain Gleizes, Diane Samélor, Constantin Vahlas, Vincent Sarou-Kanian, Pierre Florian, Dominique Massiot

\section{To cite this version:}

Alain Gleizes, Diane Samélor, Constantin Vahlas, Vincent Sarou-Kanian, Pierre Florian, et al.. Temperature Dependent 4-, 5- and 6-Fold Coordination of Aluminum in MOCVD-Grown Amorphous Alumina Films: From Local Coordination to Material Properties. Advances in Science and Technology, 2014, vol. 91, pp. 123-133. 10.4028/www.scientific.net/AST.91.123 . hal-01169598

\section{HAL Id: hal-01169598 \\ https://hal.science/hal-01169598}

Submitted on 29 Jun 2015

HAL is a multi-disciplinary open access archive for the deposit and dissemination of scientific research documents, whether they are published or not. The documents may come from teaching and research institutions in France or abroad, or from public or private research centers.
L'archive ouverte pluridisciplinaire HAL, est destinée au dépôt et à la diffusion de documents scientifiques de niveau recherche, publiés ou non, émanant des établissements d'enseignement et de recherche français ou étrangers, des laboratoires publics ou privés. 


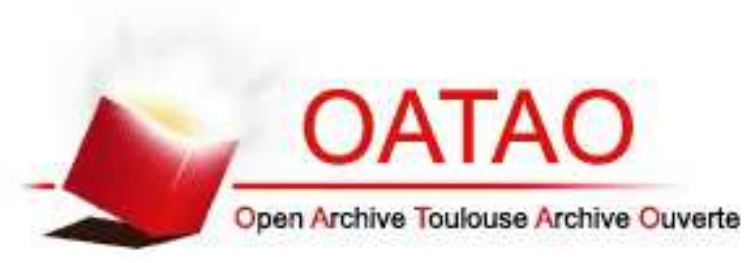

\section{Open Archive TOULOUSE Archive Ouverte (OATAO)}

OATAO is an open access repository that collects the work of Toulouse researchers and makes it freely available over the web where possible.

This is an author-deposited version published in : http://oatao.univ-toulouse.fr/ Eprints ID : 14046

To link to this article : DOI:10.4028/www.scientific.net/AST.91.123 URL : http://dx.doi.org/10.4028/www.scientific.net/AST.91.123

\section{To cite this version :}

Gleizes, Alain and Samélor, Diane and Vahlas, Constantin and Sarou-Kanian, Vincent and Florian, Pierre and Massiot, Dominique Temperature Dependent 4-, 5- and 6-Fold Coordination of Aluminum in MOCVD-Grown Amorphous Alumina Films: From Local Coordination to Material Properties. (2014) Advances in Science and Technology, vol. 91. pp. 123-133. ISSN 1662-8969

Any correspondence concerning this service should be sent to the repository administrator: staff-oatao@ listes-diff.inp-toulouse.fr 


\title{
Temperature Dependent 4-, 5- and 6-fold Coordination of Aluminum in MOCVD-grown Amorphous Alumina Films: From Local Coordination to Material Properties
}

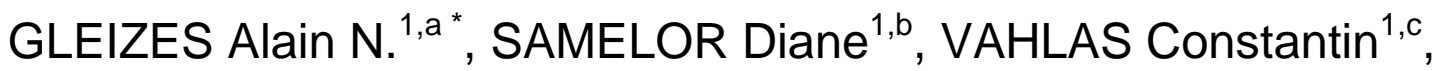 \\ SAROU-KANIAN Vincent ${ }^{2, d}$, FLORIAN Pierre ${ }^{2, e}$ and MASSIOT Dominique ${ }^{2, f}$ \\ ${ }^{1}$ CIRIMAT, Univ. Toulouse, 4 allée E. Monso, BP-44362, F-31030 Toulouse cedex 4, France \\ ${ }^{2}$ CNRS, CEMHTI UPR3079, Univ. Orléans, F-45071 Orléans cedex 2, France \\ aalain.gleizes@ensiacet.fr, ${ }^{b}$ diane.samelor@ensiacet.fr, ${ }^{\mathrm{c}}$ constantin.vahlas@ensiacet.fr \\ dvincent.sarou-kanian@cnrs-orleans.fr, ${ }^{e}$ pierre.florian@cnrs-orleans.fr, \\ 'dominique.massiot@cnrs-orleans.fr
}

Keywords: Amorphous aluminum oxide, thin film, MOCVD, very high-field NMR, pentacoordinated aluminum, mechanical properties, corrosion protection.

\begin{abstract}
Aluminum 5-fold coordination coexisting with 4- and 6-fold coordination structurally characterizes amorphous aluminum oxide. For nearly 30 years now, ${ }^{27}$ Al MAS NMR has enabled to detect and later on to quantify this feature thanks to advances in high-resolution instrumentation. The Introduction shortly reviews the results of investigations of 5-coordinate aluminum in amorphous alumina through NMR analysis. Aluminum oxide is not a glass-forming oxide. A convenient way to obtain the amorphous state is by thin film deposition. We present here ${ }^{27} \mathrm{Al}$ NMR analysis of a series of thin films of aluminum oxide prepared by metalorganic chemical vapor deposition (MOCVD) in the temperature range $360 \leq \mathrm{T}_{\mathrm{d}} \leq 720^{\circ} \mathrm{C}$. In this range, low $\mathrm{T}_{\mathrm{d}}$ yield $\mathrm{OH}-$ containing films, while high $\mathrm{T}_{\mathrm{d}}$ yield nanocrystallites-containing films. The variation of the ${ }^{[4]} \mathrm{Al}$, ${ }^{[5]} \mathrm{Al}$ and ${ }^{[6]} \mathrm{Al}$ content with $T_{d}$ is presented and discussed. It is correlated with the $T_{d}$ dependence of mechanical and corrosion protection properties. These properties are optimal when the structural disorder is to the utmost. Al coordination dependence on film thickness and the formation of metallic aluminum during the deposition process are also presented.
\end{abstract}

\section{Introduction - Review of Pentacoordinate Aluminum in Aluminum Oxide}

Like the stable form of aluminum oxide, $\alpha-\mathrm{Al}_{2} \mathrm{O}_{3}$ (corundum), the crystal forms of aluminum hydroxides [bayerite $\alpha-\mathrm{Al}(\mathrm{OH})_{3}$ and gibbsite $\gamma-\mathrm{Al}(\mathrm{OH})_{3}$ ] and oxyhydroxides [diaspore $\alpha-\mathrm{AlO}(\mathrm{OH})$ and boehmite $\gamma-\mathrm{AlO}(\mathrm{OH})]$ have all of the aluminum ions in octahedral sites $\left({ }^{[6]} \mathrm{Al}\right)$. In transition aluminum oxides $\left(\eta-, \theta-, \gamma-, \delta\right.$-, $\left.\chi-, \kappa-\mathrm{Al}_{2} \mathrm{O}_{3}\right)$, the aluminum ions occupy both tetrahedral ${ }^{[4]} \mathrm{Al}$ and octahedral ${ }^{[6]} \mathrm{Al}$ sites. Amorphous aluminas are characterized by the extra presence of pentacoordinate aluminum ions ${ }^{[5]} \mathrm{Al}$ beside ${ }^{[4]} \mathrm{Al}$ and ${ }^{[6]} \mathrm{Al}$ ones. Hereafter, we review results of studies about the distribution of these three $\mathrm{Al}$ coordination numbers in amorphous alumina according to sample type (massive, thin film, nanoparticle) and preparation conditions. Results are gathered in Table 1.

Solid-state MAS NMR is most appropriate to analyze aluminum coordination in non-crystalline or nano-crystalline solids. Evidence of penta-coordinate aluminum in amorphous alumina $\left(a-\mathrm{Al}_{2} \mathrm{O}_{3}\right)$ was first reported by Dupree et al. in 1985 [1]. The authors worked on alumina anodic films which they submitted to ${ }^{27} \mathrm{Al}$ solid-state MAS NMR with a spectrometer operating at $93.8 \mathrm{MHz}$. In order to have enough matter, several films grown under the same conditions were stripped from the aluminum substrate and assembled into one sample $[2,3]$. From the NMR lines corresponding to tetra-, penta- and hexa-coordination, the authors measured the following atom percentages for films 
grown in a solution of oxalic acid: ${ }^{[4]} \mathrm{Al}=25 \%,{ }^{[5]} \mathrm{Al}=30 \%,{ }^{[6]} \mathrm{Al}=45 \%$ [2]. However, the films were hydroxylated, which favors hexacoordination; and the material seemed inhomogeneous, with aluminum both within microcrystalline and within more disordered regions [3].

Table 1. Distribution (at.\%) of Al coordination numbers 4, 5 and 6 in amorphous alumina, according to the type of sample and the method of preparation. [6]/[4] in column 5 designates the

\begin{tabular}{|c|c|c|c|c|c|}
\hline Type of sample and method of preparation & ${ }^{[4]} \mathrm{Al}$ & ${ }^{[5]} \mathrm{Al}$ & ${ }^{[6]} \mathrm{Al}$ & {$[6] /[4]$} & ref. \\
\hline \multicolumn{6}{|l|}{ massive } \\
\hline Gibbsite calcination $200^{\circ} \mathrm{C}$ in vacuo & 25 & 20 & 55 & 2.2 & [5] \\
\hline $\begin{array}{r}\text { Gibbsite grinding + calcination } 400-500{ }^{\circ} \mathrm{C} \\
+ \text { annealing } 600{ }^{\circ} \mathrm{C} \\
+ \text { annealing } 700^{\circ} \mathrm{C}\end{array}$ & 30 & $\begin{array}{c}10 \\
6 \\
<3\end{array}$ & 60 & 2.0 & [6] \\
\hline Boehmite grinding + calcination $500-600{ }^{\circ} \mathrm{C}$ & 27.5 & 27.5 & 45 & 1.6 & \\
\hline Gibbsite partial dehydration (calcination) & 22.5 & 7.5 & 70.0 & 3.1 & [7] \\
\hline
\end{tabular}

\section{thin films}

\begin{tabular}{|c|c|c|c|c|c|c|}
\hline \multicolumn{2}{|l|}{ electrochemistry } & 25 & 30 & 45 & 1.8 & {$[2,3]$} \\
\hline \multicolumn{2}{|l|}{ PVD } & 56 & 36 & 7 & 0.1 & {$[11,12]$} \\
\hline \multicolumn{2}{|l|}{ ALD } & 54 & 41 & 5 & 0.1 & \\
\hline MOCVD (present study) & $\begin{array}{l}360^{\circ} \mathrm{C} \\
415^{\circ} \mathrm{C} \\
480^{\circ} \mathrm{C} \\
5500^{\circ} \mathrm{C} \\
600^{\circ} \mathrm{C} \\
720^{\circ} \mathrm{C}\end{array}$ & $\begin{array}{l}32.9 \\
45.6 \\
53.6 \\
53.3 \\
46.5 \\
28.6\end{array}$ & $\begin{array}{l}40.9 \\
42.9 \\
41.8 \\
39.2 \\
37.6 \\
12.2\end{array}$ & $\begin{array}{c}26.2 \\
11.5 \\
4.6 \\
7.5 \\
15.9 \\
59.2\end{array}$ & $\begin{array}{l}0.1 \\
0.3 \\
2.1\end{array}$ & {$[20]$} \\
\hline \multicolumn{7}{|l|}{ nano-particles } \\
\hline \multicolumn{2}{|c|}{$\begin{array}{r}\mathrm{Al}_{2} \mathrm{O}_{3} \text { laser vaporization }+ \text { condensation: as deposited } \\
+ \text { annealing } 600^{\circ} \mathrm{C}\end{array}$} & $\begin{array}{l}19 \\
27\end{array}$ & $\begin{array}{l}67 \\
54\end{array}$ & $\begin{array}{l}14 \\
19\end{array}$ & $\begin{array}{l}0.7 \\
0.7\end{array}$ & {$[13]$} \\
\hline
\end{tabular}

The presence of penta-coordinate aluminum in massive alumina was detected in 1991 through the ${ }^{27} \mathrm{Al}$ MAS NMR analysis of the amorphous variety called $\rho-\mathrm{Al}_{2} \mathrm{O}_{3}$ [4]. This variety results from in vacuo partial dehydration of gibbsite. It shows an 'amorphous' X-ray pattern [4], or 'only a few diffuse lines in its X-ray powder diffraction pattern' [5]. The respective atom percentages of ${ }^{[4]} \mathrm{Al}$, ${ }^{[5]} \mathrm{Al}$ and ${ }^{[6]} \mathrm{Al}$ were quantified to 25,20 and 55\% [5]. At about the same time, Chen et al. published a study on aluminas obtained by calcining finely divided gibbsite and boehmite between 400 and $800^{\circ} \mathrm{C}$. From ${ }^{27} \mathrm{Al}$ MAS NMR, the 'X-ray amorphous aluminas' obtained from boehmite had the composition ${ }^{[4]} \mathrm{Al} \approx{ }^{[5]} \mathrm{Al}=27.5 \%,{ }^{[6]} \mathrm{Al}=45 \%$ for calcination temperature between 500 and $600{ }^{\circ} \mathrm{C}$ [6]. Those obtained from gibbsite were less stable, having the composition ${ }^{[4]} \mathrm{Al}=30 \%,{ }^{[5]} \mathrm{Al}=$ $10 \%,{ }^{[6]} \mathrm{Al}=60 \%$ for calcination temperature between 400 and $500{ }^{\circ} \mathrm{C}$; above $600{ }^{\circ} \mathrm{C}$ their ${ }^{[5]} \mathrm{Al}$ content decreased to about $6 \%$ at $600^{\circ} \mathrm{C}$ and it was below $3 \%$ at $700^{\circ} \mathrm{C}$ [6]. Kunath-Fandrei et al., still using ${ }^{27} \mathrm{Al}$ MAS NMR, measured ${ }^{[4]} \mathrm{Al}=22.5 \%,{ }^{[5]} \mathrm{Al}=7.5 \%$ and ${ }^{[6]} \mathrm{Al}=70.0 \%$ for 'an amorphous partially dehydrated alumina formed by calcining gibbsite' [7]. A small amount (ca. 5\%) of ${ }^{[5]} \mathrm{Al}$, supposedly surface species, was also reported for $\gamma-\mathrm{Al}_{2} \mathrm{O}_{3}$ formed upon thermal decomposition of boehmite $(\gamma-\mathrm{AlOOH})$ [8-10].

Using ${ }^{27} \mathrm{Al}$ MAS NMR experiments operating at a magnetic field of 9.4T, Lee et al. recently showed that two a- $\mathrm{Al}_{2} \mathrm{O}_{3}$ films grown by physical vapor deposition (PVD) [11] and atomic layer deposition (ALD) [12] mainly consist of tetra-coordinate and penta-coordinate aluminum sites with a low content of hexa-coordinate aluminum sites $\left({ }^{[4]} \mathrm{Al}, 56\right.$ for PVD, 54 for $\mathrm{ALD} ;{ }^{[5]} \mathrm{Al}, 36$ for PVD, 
41 for ALD; ${ }^{[6]} \mathrm{Al}, 7$ for PVD, 5 for ALD; all in atom \%). This was actually the first MAS NMR study for amorphous alumina thin films not detached from the substrate. The substrate was $200 \mu \mathrm{m}$ thick silicon wafer. Powder samples for ${ }^{27} \mathrm{Al}$ NMR analysis were prepared by grinding the coated substrate. To increase the $\mathrm{Al} / \mathrm{Si}$ mass ratio, the authors reduced the thickness of the substrate down to $100 \mu \mathrm{m}$ by chemically attacking the non-coated face. Incidentally, in this paper we report on an easier way to obtain NMR samples with acceptable $\mathrm{Al} /$ substrate mass ratio.

Very recently, Tavakoli et al. published results concerning amorphous alumina nanoparticles [13]. The nanoparticles were obtained by laser evaporating $\mathrm{Al}_{2} \mathrm{O}_{3}$ targets and condensing the vapor phase on a stainless-steel support. As-deposited nanoparticles and particles annealed at $600{ }^{\circ} \mathrm{C}$ were amorphous (XRD and TEM) and had average sizes of $3.6 \pm 0.4 \mathrm{~nm}$ and $4.8 \pm 0.5 \mathrm{~nm}$ respectively. From ${ }^{27} \mathrm{Al}$ MAS NMR, the relative fractions for four-, five-, and six-coordinated Al ions were respectively 19,67 , and 14 at.\% for as-deposited particles and 27,54 , and 19 at.\% for nanoparticles annealed at $600{ }^{\circ} \mathrm{C}$.

Five-coordinated aluminum is also present in liquid alumina. High-temperature NMR experiments revealed an average Al coordination number of about 4.5-4.9 [14-18]. The rapid exchange between the different aluminum coordination geometries results in one single NMR resonance peak, making the quantification of sites population less straightforward than in the solid state. The simultaneous presence of ${ }^{[4]} \mathrm{Al},{ }^{[5]} \mathrm{Al}$ and ${ }^{[6]} \mathrm{Al}$ was confirmed through diffraction experiments combined with modeling approaches. The most recent of these studies shows that liquid alumina near its melting point is composed predominantly of ${ }^{[4]} \mathrm{Al}$ and ${ }^{[5]} \mathrm{Al}$ sites in the approximate ratio of $2: 1$, with minor fractions of ${ }^{[3]} \mathrm{Al}$ and ${ }^{[6]} \mathrm{Al}$ sites [19]. It is worth noting that metallic aluminum $\mathrm{Al}^{0}$ was detected by NMR in a droplet of alumina rapidly cooled from the melt under inert atmosphere [17].

Having long processed thin films of aluminum oxide by metalorganic chemical vapor deposition (MOCVD), we have focused our interest in the relationship between processing conditions, structural features and properties of the films. MOCVD-processed alumina thin films are "X-ray amorphous" up to deposition temperature of $700{ }^{\circ} \mathrm{C}$. Recently we published the results of a ${ }^{27} \mathrm{Al}$ NMR study of a series of six amorphous thin films deposited in the temperature range $360-720{ }^{\circ} \mathrm{C}$ [20]. This was the first study on the influence of deposition temperature on aluminum coordination number. Thanks to the use of a very high field $(20 \mathrm{~T})$ spectrometer, the $1 \mathrm{D}$ and $2 \mathrm{D}$ spectra could be collected for the six samples in reasonably short lengths of time. The study was completed with the investigation of proton through $\left\{{ }^{1} \mathrm{H}\right\}^{27} \mathrm{Al}$ rotational echo double resonance (REDOR) for the samples containing $\mathrm{OH}$ groups. The details of this thorough NMR investigation are given in reference [20]. Here we focus on relationship between temperature of deposition, hydroxylation rate, order range, aluminum coordination numbers and some physical properties.

\section{Experimental}

Thin Films Preparation. The films examined in this study were grown in a custom-made, horizontal, hot-wall reactor described in a previous paper [21]. Supercooled ATI (Acros Organics) was heated at $90{ }^{\circ} \mathrm{C}$ and the vapor phase was carried to the deposition zone by bubbling with 99.9992\% pure $\mathrm{N}_{2}$ (Air Products). Fixed experimental parameters were as follows: total pressure, $0.67 \mathrm{kPa} ; \mathrm{N}_{2}$ flow rate over ATI, 20 standard cubic centimeters per minute $(\mathrm{sccm})$; and dilution $\mathrm{N}_{2}$ flow rate, $631 \mathrm{sccm}$. Film thickness was determined from weight gain of the samples and by reflectometry using a UV-VIS reflectometer (Ocean Optics) and NanoCalc software.

\section{NMR Analysis}

Samples for NMR. Six films with targeted thickness of $0.5 \pm 0.1 \mu \mathrm{m}$ were grown on $100 \mu \mathrm{m}$ thick, (100) oriented silicon wafers at $360,420,480,550,600$, and $720^{\circ} \mathrm{C}$. Three more samples with targeted thickness $0.1,0.2$, and $1 \mu \mathrm{m}$ were prepared at $480{ }^{\circ} \mathrm{C}$ in order to gain insight into possible structural evolution along the thickness of the film. The samples, comprising the oxide film and the wafer, were then ground into a coarse powder for packing in the NMR sample container. 
NMR experiments. Solid-state ${ }^{27}$ Al NMR experiments were carried out on a Bruker AVANCE III spectrometer operating at a magnetic field of $20.0 \mathrm{~T}$ (Larmor frequency of $221.5 \mathrm{MHz}$ ). The available volume for the powder sample in the $2.5 \mathrm{~mm}$ MAS probe head was $14 \mu \mathrm{L}$. Details about acquisition and treatment of one-dimensional (1D) MAS and two-dimensional (2D) MQMAS spectra are given in reference [20]. Among the four samples prepared at $480{ }^{\circ} \mathrm{C}$, only the thickest one was submitted to 3QMAS NMR because the amount of aluminum for the thinnest films (i.e., the smallest ratio alumina/wafer) would necessitate unpractical experimental times. All spectra were referenced with respect to a $1 \mathrm{M}$ solution of $\mathrm{Al}\left(\mathrm{NO}_{3}\right)_{3}$. 1D and $2 \mathrm{D}$ spectra were simulated using the Dmfit software [22].

\section{Results}

Composition and Amorphicity/Crystallinity of the Films. An important point is that there are two families of films according to whether they contain $\mathrm{OH}$ groups or not [23]. The films grown at 360 and $420^{\circ} \mathrm{C}$ contain $\mathrm{OH}$ and are formulated $\mathrm{AlO}_{1+x}(\mathrm{OH})_{1-2 x}$, with $x$ increasing from $0[\mathrm{AlO}(\mathrm{OH})$ or $\mathrm{O} / \mathrm{Al}=2]$ to $1 / 2\left[\mathrm{Al}_{2} \mathrm{O}_{3}\right.$ or $\left.\mathrm{O} / \mathrm{Al}=1.5\right]$. For $\mathrm{T}_{\mathrm{d}}=350{ }^{\circ} \mathrm{C}$, the $\mathrm{O} / \mathrm{Al}$ atomic ratio is 2 . The films grown at 550,600, and $720{ }^{\circ} \mathrm{C}$ are non-hydroxylated $\mathrm{Al}_{2} \mathrm{O}_{3}$. The temperature frontier between hydroxylated and non-hydroxylated films has not been ascertained. It is estimated at about $450{ }^{\circ} \mathrm{C}$, so that the film grown at $480{ }^{\circ} \mathrm{C}$ can be considered as non-hydroxylated $\mathrm{Al}_{2} \mathrm{O}_{3}$.

In previous studies [21], we established that the films processed in the temperature range 350 $550{ }^{\circ} \mathrm{C}$ show no $\mathrm{XRD}$ lines, and that those grown at $700{ }^{\circ} \mathrm{C}$ show wide, ill-defined diffraction peaks corresponding to $\gamma-\mathrm{Al}_{2} \mathrm{O}_{3}$. Well-crystallized $\gamma-\mathrm{Al}_{2} \mathrm{O}_{3}$ forms upon annealing for $1 \mathrm{~h}$ at $800{ }^{\circ} \mathrm{C}$ under nitrogen flow. We also observed in the TEM that a film grown at $700{ }^{\circ} \mathrm{C}$ is embedded with nanocrystals of $\gamma-\mathrm{Al}_{2} \mathrm{O}_{3}$ while no such crystals form in a film grown at $550^{\circ} \mathrm{C}$ [23]. Therefore, the samples presented here can be classified into three categories: amorphous hydroxylated alumina (a$\left.\mathrm{AlO}_{1+x} \mathrm{OH}_{1-2 x}\right)$ for $\mathrm{T}_{\mathrm{d}}=360$ and $420{ }^{\circ} \mathrm{C}$; amorphous non-hydroxylated alumina $\left(\mathrm{a}-\mathrm{Al}_{2} \mathrm{O}_{3}\right)$ for $\mathrm{T}_{\mathrm{d}}=$ 480, 550 and $600{ }^{\circ} \mathrm{C}$; amorphous non-hydroxylated alumina embedded with nanocrystals of $\gamma-\mathrm{Al}_{2} \mathrm{O}_{3}$ $\left(\mathrm{a}-\mathrm{Al}_{2} \mathrm{O}_{3}+\gamma-\mathrm{Al}_{2} \mathrm{O}_{3}\right)$ for $\mathrm{T}_{\mathrm{d}}=720^{\circ} \mathrm{C}$.

Aluminum coordination. As illustrations of the quality of the NMR spectra, Figure 1 shows the 1D quantitative ${ }^{27} \mathrm{Al}$ spectra and the $2 \mathrm{D} 3 \mathrm{QMAS}{ }^{27} \mathrm{Al}$ spectra for the films grown at 420, 550 and $720^{\circ} \mathrm{C}$. The spectral resolution resulting from the very high magnetic field $(20 \mathrm{~T})$ allows a clear identification of the tetra-, penta-, and hexa-coordinated aluminum sites $\left({ }^{[\mathrm{n}]} \mathrm{Al}\right.$ with $\mathrm{n}=4$, 5, or 6 ). Their line shapes are characteristic of a typical amorphous structure as seen in alumina-containing glasses [22]. The simulation of such NMR spectra is based on the "Czjzek" model (or Gaussian isotropic model) [24-26]. The NMR parameters deduced from this model are the averaged isotropic chemical shift $\left(\overline{\delta_{\text {iso }}}\right)$, the chemical shift distribution $(\Delta \mathrm{CS})$, and the averaged quadrupolar constant $\left(\overline{\mathrm{C}_{\mathrm{Q}}}\right)$. As shown recently [27] for ${ }^{27} \mathrm{Al}, \overline{\delta_{\text {iso }}}$ is mainly governed by chemical modifications in the second coordination sphere, while $\overline{\mathrm{C}_{\mathrm{Q}}}$ measures the distortion (bond lengths and/or angles) of the $\mathrm{AlO}_{\mathrm{n}}$ polyhedrons in which the $\mathrm{Al}-\mathrm{O}$ bonds have some covalent character, that is the $\mathrm{AlO}_{4}$ tetrahedra mainly. $\triangle \mathrm{CS}$ measures the amount of disorder, in other words the width of the bond angle and bond distances distributions. It broadens the NMR lines in such a way that it is difficult to disentangle it from the broadening due to the distribution of $\mathrm{C}_{\mathrm{Q}}$ without the help of a $2 \mathrm{D}$ experiment spreading the information in a second dimension.

As the 3QMAS spectra have fully separated the three ${ }^{[n]} \mathrm{Al}$ sites (Figure 1), they were first simulated in order to obtain primary sets of optimized values of $\overline{\delta_{\text {iso }}}, \Delta \mathrm{CS}$ and $\overline{\mathrm{C}_{\mathrm{Q}}}[20]$. The $1 \mathrm{D}{ }^{27} \mathrm{Al}$ MAS spectra were reconstructed by optimizing nine parameters $\left(\overline{\delta_{\text {iso }}}, \overline{\mathrm{C}_{\mathrm{Q}}}\right.$, amplitude) while keeping the $\triangle \mathrm{CS}$ values as issued from the $3 \mathrm{QMAS}$ experiment. The percentages of each ${ }^{[\mathrm{n}]} \mathrm{Al}$ site was calculated from line shape integration of the central transition. The optimized values are in Table 1. 

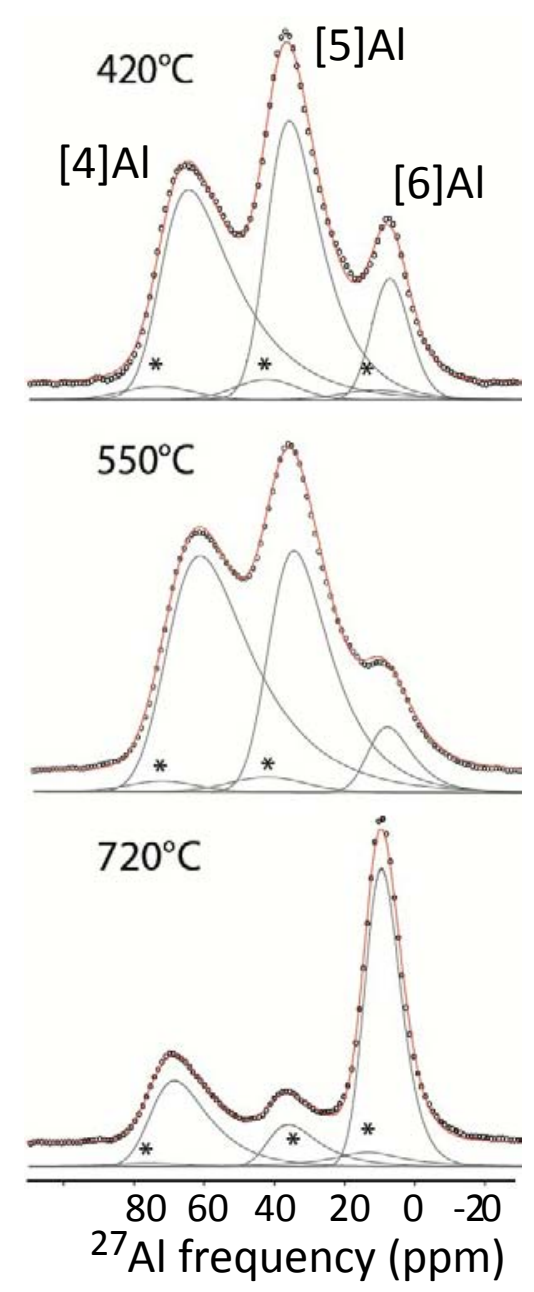
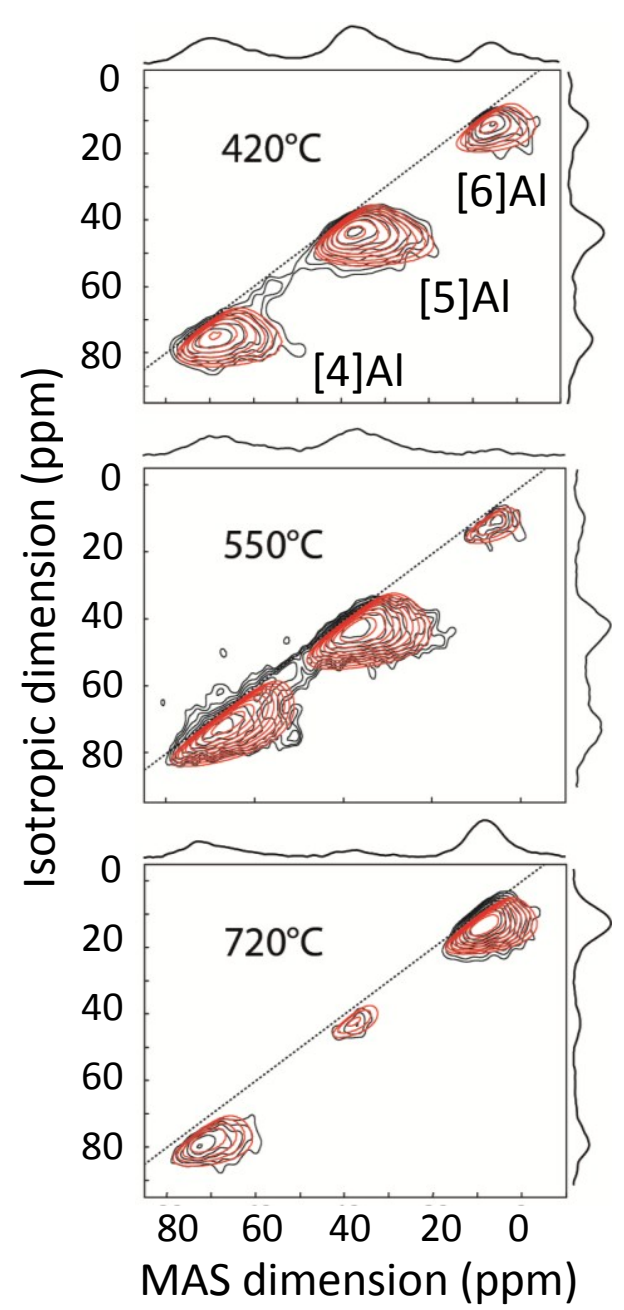

Figure 1. ${ }^{27} \mathrm{Al}$ NMR spectra for films deposited at 420,550 and $720{ }^{\circ} \mathrm{C}$. Left: experimental (dots) and reconstructed (red) 1-D MAS spectra of the central transitions of the three ${ }^{[\mathrm{n}]} \mathrm{Al}$ sites. The grey lines refer to the contributions to the reconstructed spectra. Asterisks show the spinning sidebands of the external transitions. The center bands were simulated with Gaussian line shapes accounting for the line widths and intensities of their neighboring sidebands. Right: experimental and simulated (red) 2-D ${ }^{27} \mathrm{Al} 3$ QMAS spectra of the films. The full set of spectra relative to this study is given in reference [20].

Figure 2 shows the evolution of the percentages of ${ }^{[n]} \mathrm{Al}$ sites and of $\Delta \mathrm{CS}$ with $\mathrm{T}_{\mathrm{d}}$. The respective percentages of tetra- and hexa-coordinated sites vary with opposite trends. The ${ }^{[4]} \mathrm{Al}$ content increases from $33 \%$ for $\mathrm{T}_{\mathrm{d}}=360{ }^{\circ} \mathrm{C}$ up to $53 \%$ for $\mathrm{T}_{\mathrm{d}}=480{ }^{\circ} \mathrm{C}$; at the same time, the ${ }^{[6]} \mathrm{Al}$ content decreases from $26 \%$ to $5 \%$. For $\mathrm{T}_{\mathrm{d}}=550{ }^{\circ} \mathrm{C}$, the respective percentages have values that are nearly the same as those for $480{ }^{\circ} \mathrm{C}$, suggesting that the maximum of ${ }^{[4]} \mathrm{Al}$ sites and the minimum of ${ }^{[6]} \mathrm{Al}$ sites occur for $\mathrm{T}_{\mathrm{d}} \sim 515{ }^{\circ} \mathrm{C}$. From 360 to $515{ }^{\circ} \mathrm{C}$, the ${ }^{[5]} \mathrm{Al}$ content is at its highest with values between $40 \%$ and $43 \%$. It can be noticed that the ${ }^{[\mathrm{n}]} \mathrm{Al}$ percentages measured for $\mathrm{T}_{\mathrm{d}}=480{ }^{\circ} \mathrm{C}$ (and $550{ }^{\circ} \mathrm{C}$ ) compare well with those measured by Lee et al. for two aluminum oxide films prepared by PVD and ALD $[11,12]$ (Table 1). In the $550-720{ }^{\circ} \mathrm{C}$ range, the ${ }^{[6]} \mathrm{Al}$ content increases to $59 \%$ and the ${ }^{[4]} \mathrm{Al}$ and ${ }^{[5]} \mathrm{Al}$ contents decrease to $29 \%$ and $12 \%$, respectively.

The average isotropic chemical shift $\overline{\delta_{\text {iso }}}$ does not present any significant evolution with $\mathrm{T}_{\mathrm{d}}$, consistent with the fact that there are no chemical variations in the aluminum second coordination sphere (i.e., only $\mathrm{Al}$ atoms) [20]. The average values of $\overline{\mathrm{C}_{\mathrm{Q}}}$ and $\Delta \mathrm{CS}$ between the three ${ }^{[\mathrm{n}]} \mathrm{Al}$ sites show the same hierarchy whatever the temperature of deposition: $\overline{\mathrm{C}_{\mathrm{Q}}}\left({ }^{[4]} \mathrm{Al}\right)>\overline{\mathrm{C}_{\mathrm{Q}}}\left({ }^{[5]} \mathrm{Al}\right)>\overline{\mathrm{C}_{\mathrm{Q}}}\left({ }^{[6]} \mathrm{Al}\right)$ and $\Delta \mathrm{CS}\left({ }^{[4]} \mathrm{Al}\right)>\Delta \mathrm{CS}\left({ }^{[5]} \mathrm{Al}\right)>\Delta \mathrm{CS}\left({ }^{[6]} \mathrm{Al}\right)[20]$. The same $\overline{\mathrm{C}_{\mathrm{Q}}}$ trend was observed for rare-earth 
aluminosilicates $[28,29]$ and may be related to polyhedra-specific distortions. Figure 2 shows that $\triangle \mathrm{CS}$ is maximal for a $\mathrm{T}_{\mathrm{d}}$ half-way between 480 and $550{ }^{\circ} \mathrm{C}$ for each coordination number. This suggests that the utmost structural disorder corresponds to the highest rates of ${ }^{[4]} \mathrm{Al}$ and ${ }^{[5]} \mathrm{Al}$ sites.

The average coordination number $\mathrm{CN}_{\mathrm{av} .}=\left[4\left({ }^{[4]} \mathrm{Al}\right.\right.$ at.\% $)+5\left({ }^{[5]} \mathrm{Al}\right.$ at.\%) $+6\left({ }^{[6]} \mathrm{Al}\right.$ at.\%) $] / 100$, decreases from 4.93 for $\mathrm{T}_{\mathrm{d}}=360^{\circ} \mathrm{C}$ down to 4.50 for $\mathrm{T}_{\mathrm{d}} \sim 515^{\circ} \mathrm{C}$, and then increases up to 5.31 for $\mathrm{T}_{\mathrm{d}}=720^{\circ} \mathrm{C}$.

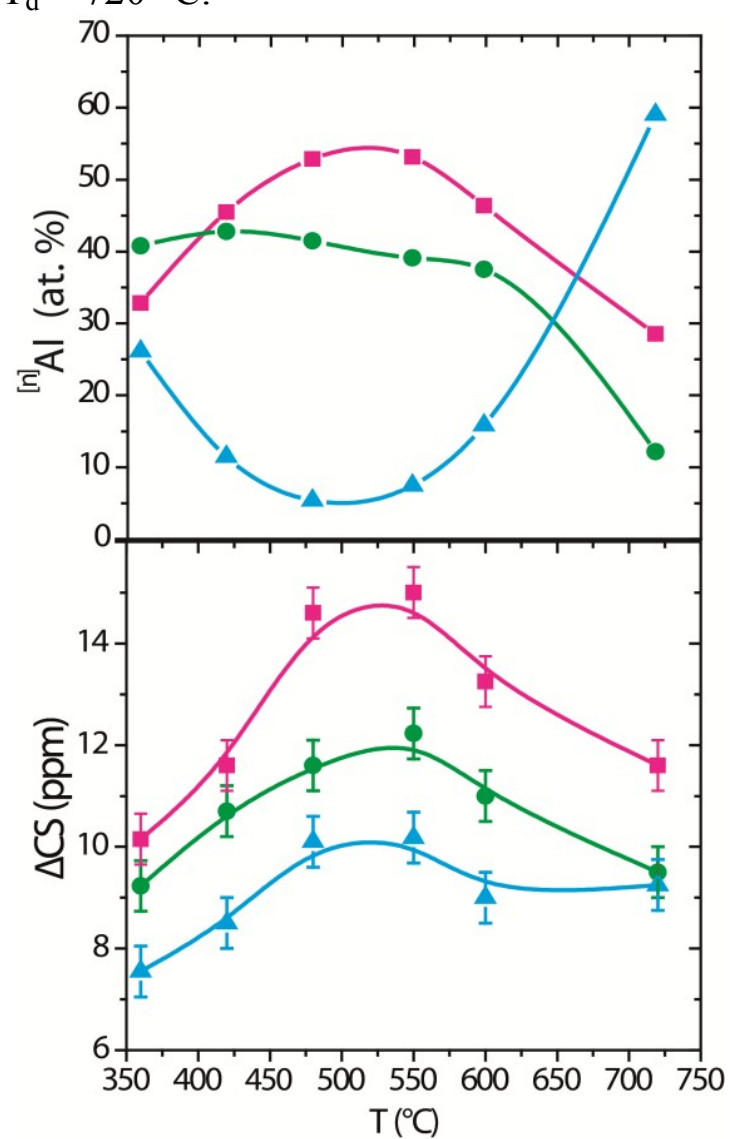

Figure 2. Atom percentages of ${ }^{[4]} \mathrm{Al}$ (squares) ${ }^{[5]} \mathrm{Al}$ (circles) and ${ }^{[6]} \mathrm{Al}$ (triangles) sites (top) and the corresponding chemical shift distributions (bottom) versus deposition temperature. Lines are a guide to the eye.
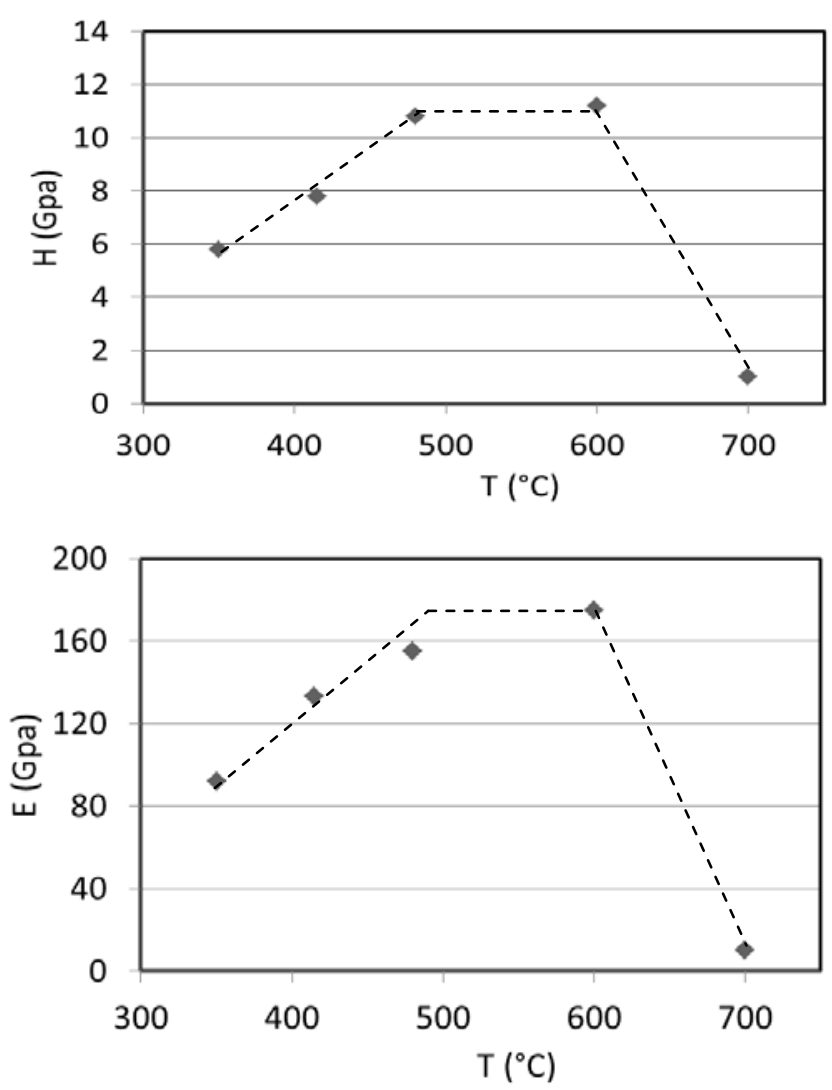

Figure 3. Hardness (top) and Young's modulus (bottom) measured for alumina films grown at different temperatures. The substrate was Ti6Al4V for the films grown at 350,480 and $700{ }^{\circ} \mathrm{C}$ and silicon for the films grown at 415 and $600{ }^{\circ} \mathrm{C}$. Lines are a guide to the eye.

Mechanical properties. Hardness and Young's modulus were calculated from nanoindentation measurements for three films deposited on commercial Ti6Al4V titanium alloy at 350, 480 and 700 ${ }^{\circ} \mathrm{C}$, and two films deposited on silicon at 415 and $600{ }^{\circ} \mathrm{C}$ [30]. Figure 3 shows hardness and Young's modulus variations with the temperature of deposition. There is a striking apparent relation with the variations of ${ }^{[n]} \mathrm{Al}$ atom \%. Both properties increase nearly linearly with the temperature between 360 and $480{ }^{\circ} \mathrm{C}$, reach a plateau or a flattened maximum between 500 and $600{ }^{\circ} \mathrm{C}$, and decrease abruptly between 600 and $700{ }^{\circ} \mathrm{C}$.

The films grown at 350 and $415^{\circ} \mathrm{C}$ contain $\mathrm{OH}$ groups, with respective atomic ratios $\mathrm{O} / \mathrm{Al}$ about 2.0 and 1.6. The respective Young's moduli are 92 and $133 \mathrm{GPa}$, showing an increase with decreasing $\mathrm{OH}$ content. This agrees with results obtained by Kijima and Hanada [31] for diversely hydroxylated $(1.55<\mathrm{O} / \mathrm{Al}<1.75)$ amorphous alumina films deposited by rf-sputtering. They observed a linear dependence of Young's modulus on the atomic ratio O/Al. However their values were smaller than in the present study, for instance 75 and $115 \mathrm{GPa}$ for $\mathrm{O} / \mathrm{Al}=1.75$ and 1.60 respectively. The extrapolated value for $\mathrm{O} / \mathrm{Al}=1.5$ was $141 \mathrm{GPa}$, to be compared with $155 \mathrm{GPa}$ in the present study for the film grown at $480{ }^{\circ} \mathrm{C}$. 
The values measured for the film grown at $415^{\circ} \mathrm{C}(\mathrm{H}=7.8 \mathrm{GPa}, \mathrm{E}=133 \mathrm{GPa})$ in the present study compare with those reported by Alcala et al. for an amorphous anodic alumina film : $\mathrm{H}=7.0$ $\mathrm{GPa}, \mathrm{E}=122 \mathrm{GPa}$ [32]. Amorphous anodic alumina is known to contain $\mathrm{OH}[2,3]$.

The hardness $(11.2 \mathrm{GPa})$ and Young's modulus $(175 \mathrm{GPa})$ of the film grown at $600{ }^{\circ} \mathrm{C}$ compare with those measured by Nakao et al. for a $600 \mathrm{~nm}$ thick film grown on $\mathrm{Si}(100)$ by rf-sputtering (11.0 and $181 \mathrm{GPa}$ respectively) [33]. They also compare with values measured by Barbour et al. for several hundred $\mathrm{nm}$ thick films deposited on $\mathrm{Si}(100)$ at varied temperatures using electron-beam evaporation of aluminum and co-bombardment with $\mathrm{O}_{2}{ }^{+}$ions from an electron-cyclotron resonance plasma $\left(11.1\right.$ and $187 \mathrm{GPa}$ at $400{ }^{\circ} \mathrm{C} ; 9.6$ and $177 \mathrm{GPa}$ at $170{ }^{\circ} \mathrm{C} ; 9.5$ and $170 \mathrm{GPa}$ at $\left.145^{\circ} \mathrm{C}\right)$ [34].

Interesting with respect to the present study, Natali et al. measured the hardness and Young's modulus of three films of non-hydroxylated amorphous alumina prepared by the MOCVD technique at $380{ }^{\circ} \mathrm{C}$ and annealed at 500 and $700{ }^{\circ} \mathrm{C}$ [35]. Hardness values of 10.9, 11.9 and 10.6 GPa for the preparation or annealing temperatures of 380,500 and $700{ }^{\circ} \mathrm{C}$ respectively compare quite well with those for the films obtained at $480{ }^{\circ} \mathrm{C}(10.8 \mathrm{GPa})$ and $600{ }^{\circ} \mathrm{C}(11.2 \mathrm{GPa})$ in the present study. The corresponding Young's modulus $(184.3,198.3$ and $178.9 \mathrm{GPa})$ are slightly larger than the larger ones in the present study. However it is worth noting that the highest values in Natali et al.'s study $(\mathrm{H}=11.9 \mathrm{GPa}, \mathrm{E}=198.3 \mathrm{GPa})$ are observed for the film annealed at $500{ }^{\circ} \mathrm{C}$, that is on the plateau evidenced in the present study. On the contrary, the film annealed at $700{ }^{\circ} \mathrm{C}$ in Natali et al.'s work $(\mathrm{H}=10.6 \mathrm{GPa}, \mathrm{E}=178.9 \mathrm{GPa})$ behaves quite differently from the one grown at $700{ }^{\circ} \mathrm{C}$ in the present study $(\mathrm{H} \sim 1 \mathrm{GPa}, \mathrm{E} \sim 10 \mathrm{GPa})$.

Protection against corrosion. To study corrosion protection, thin films of alumina were deposited at 350,480 and 700 [36] or $750{ }^{\circ} \mathrm{C}$ [37] on Ti6Al4V titanium alloy. Polarization curves in a $0.1 \mathrm{M}$ $\mathrm{NaCl}$ solution showed that the lowest corrosion potential corresponded to the film deposited at $350{ }^{\circ} \mathrm{C}$ and was close to that of the bare alloy. This film resulted also in the highest anodic and cathodic current densities. The films deposited at 480 and 700 or $750{ }^{\circ} \mathrm{C}$ gave higher corrosion potentials. Moreover the film deposited at $480{ }^{\circ} \mathrm{C}$ gave lower anodic and cathodic current densities that the ones deposited at 700 and $750{ }^{\circ} \mathrm{C}$. So the polarization curves in a $0.1 \mathrm{M} \mathrm{NaCl}$ solution clearly showed that the amorphous $\mathrm{Al}_{2} \mathrm{O}_{3}$ film deposited at $480{ }^{\circ} \mathrm{C}$ gave better corrosion protection than the amorphous $\mathrm{AlO}(\mathrm{OH})$ film deposited at $350{ }^{\circ} \mathrm{C}$ or the partially nanocrystallized $\mathrm{Al}_{2} \mathrm{O}_{3}$ films deposited at 700 and $750{ }^{\circ} \mathrm{C}$. Electrical impedance measured after $1 \mathrm{~h}$ in the $\mathrm{NaCl}$ solution showed that the film deposited at $480{ }^{\circ} \mathrm{C}$ improved corrosion resistance by nearly 2 orders of magnitude: the impedance moduli measured at $20 \mathrm{Mhz}$ were $2.3 \times 10^{7} \Omega . \mathrm{cm}^{2}$ for $\mathrm{T}_{\mathrm{d}}=480{ }^{\circ} \mathrm{C}$ to compare with $3.6 \times 10^{5} \Omega . \mathrm{cm}^{2}$ and $7.4 \times 10^{5} \Omega . \mathrm{cm}^{2}$ for $\mathrm{T}_{\mathrm{d}}=350{ }^{\circ} \mathrm{C}$ and $750{ }^{\circ} \mathrm{C}$ respectively [37]. Electrochemical impedance spectroscopy was also applied to films deposited on $304 \mathrm{~L}$ stainless steel at $480{ }^{\circ} \mathrm{C}$ [38]. The good barrier properties of the alumina films deposited at $480{ }^{\circ} \mathrm{C}$ were confirmed. They improve significantly on increasing the thickness up to a threshold of $c a .500-600 \mathrm{~nm}$.

Formation of metallic aluminum $\mathrm{Al}^{\mathbf{0}}$. Figure 4 shows the $1 \mathrm{D}$ quantitative ${ }^{27} \mathrm{Al}$ spectrum in the frequency range $1400-1800 \mathrm{ppm}$ for a $85 \mathrm{~nm}$ thick film processed at $\mathrm{T}_{\mathrm{d}}=480{ }^{\circ} \mathrm{C}$. The spectrum clearly reveals a peak at $1650 \mathrm{ppm}$ corresponding to metallic aluminum $\mathrm{Al}^{0}$. The film belongs to a series of four deposits processed at $480{ }^{\circ} \mathrm{C}$ with varying thickness: $85,180,600$, and $940 \mathrm{~nm}$. The aim was to gain insight into possible structural evolution along deposited alumina thickness. The presence of metallic aluminum was unexpected. The unexpected peak at $1650 \mathrm{ppm}$ did not show up on a 1D $27 \mathrm{Al}$ spectrum recorded with the bare silicon substrate. Moreover, its relative intensity decreased $(0.018,0.010,0.003)$ with increasing thickness $(85,180,600 \mathrm{~nm})$ [20]. These two observations lead to the conclusion that metallic aluminum does form during alumina growth, and that it forms as a very thin layer at the silicon/alumina interface. As reminded in the Introduction, metallic aluminum was detected by NMR in a droplet of alumina rapidly cooled from the melt $(\sim$ $2350{ }^{\circ} \mathrm{C}$ ) under inert atmosphere [17]. Here also alumina was processed under inert atmosphere (99.9992\% pure $\mathrm{N}_{2}$ ), but the temperature was $\sim 2000$ degrees lower. 


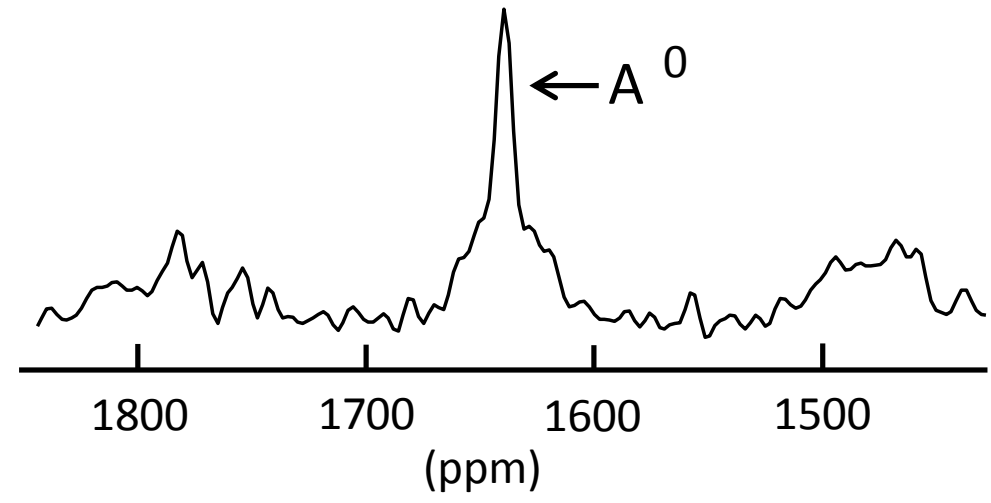

Figure 4. Detailed region of the 1D quantitative spectrum for the $85 \mathrm{~nm}$ thick coating grown at $480{ }^{\circ} \mathrm{C}$

Film Thickness Dependence of the Structure. The NMR analysis of the four films deposited at $480{ }^{\circ} \mathrm{C}$ with varying thickness shows that the distribution of ${ }^{[\mathrm{n}]} \mathrm{Al}$ sites is slightly different in the thinnest film $(85 \mathrm{~nm})$ comparatively to the three thicker ones $(180,600,936 \mathrm{~nm})$. The percentages of ${ }^{[6]} \mathrm{Al}$ sites do not differ significantly with increasing thickness: $5.6 \pm 0.9,5.3 \pm 0.7,5.4 \pm 0.4,4.6$ $\pm 0.9 \%$. But the corresponding values for ${ }^{[5]} \mathrm{Al}$ and ${ }^{[4]} \mathrm{Al}$ are respectively: $43.7 \pm 0.7,41.0 \pm 0.6$, $41.6 \pm 0.4,41.8 \pm 0.7 \%$, and $50.7 \pm 1.0,53.7 \pm 0.8,53.0 \pm 0.6,53.6 \pm 0.6 \%$. Compared to the thicker films, the thinner one contains a little excess of ${ }^{[5]} \mathrm{Al}$ sites and a little deficit of ${ }^{[4]} \mathrm{Al}$ sites. Although formally significant, these variations may be questioned. They might sign a size effect. Tavakoli et al. observed that the large amount of $67 \%$ of ${ }^{[5]} \mathrm{Al}$ sites in as-deposited amorphous alumina nanoparticles having an average size of $3.6 \mathrm{~nm}$ dropped down to $54 \%$ when the average size increased to $4.8 \mathrm{~nm}$ upon heating at $600{ }^{\circ} \mathrm{C}$. In the same time, the respective percentages of ${ }^{[4]} \mathrm{Al}$ and ${ }^{[6]} \mathrm{Al}$ sites increased from 19 to 27 and from 14 to 19 [13]. The observed changes in ${ }^{[5]} \mathrm{Al}$ and ${ }^{[4]} \mathrm{Al}$ contents in the $85 \mathrm{~nm}$ thick film might well be the starting of the increasing amorphous character of the deposit for very weak thickness.

Concluding remarks. The "most amorphous structure" is that of $\mathrm{Al}_{2} \mathrm{O}_{3}$ grown between 480 and $550{ }^{\circ} \mathrm{C}$. This structure is the less propitious to grain boundary formation. Moreover, it corresponds to the minimal average coordination number $(\sim 4.50)$, hence the most covalent character of the structure. These are key features for the mechanical and diffusion barrier properties of alumina. Further studies are needed to be more specific about the structure-properties relationship.

The collapse of hardness and elastic modulus between 600 and $700{ }^{\circ} \mathrm{C}$ might result from the formation of a biphasic amorphous/crystalline structure. It is recalled that embedded nanocrystals of $\gamma$-A12O3 were observed in the TEM for $\mathrm{T}_{\mathrm{d}}=700{ }^{\circ} \mathrm{C}$ while there were no such crystals in a film grown at $550^{\circ} \mathrm{C}$ [23]. The structure of $\gamma-\mathrm{Al}_{2} \mathrm{O}_{3}$ is made of tetrahedral ${ }^{[4]} \mathrm{Al}$ and octahedral ${ }^{[6]} \mathrm{Al}$ sites in the atomic ratio ${ }^{[6]} \mathrm{Al} /{ }^{[4]} \mathrm{Al} \geq 2$. This ratio (Table 1) is equal to 0.1 and 0.3 for $\mathrm{T}_{\mathrm{d}}=550$ and 600 ${ }^{\circ} \mathrm{C}$ respectively: for lack of octahedral $\mathrm{Al}$ ions, $\gamma-\mathrm{Al}_{2} \mathrm{O}_{3}$ cannot form at these temperatures. The ratio rapidly increases up to $\sim 1$ at about $660{ }^{\circ} \mathrm{C}$ and $\sim 2$ at about $700{ }^{\circ} \mathrm{C}$. The decreasing content in ${ }^{[5]} \mathrm{Al}$ is still $12 \%$ at $720{ }^{\circ} \mathrm{C}$. All of this is consistent with the spread formation of nanocrystals of $\gamma-\mathrm{Al}_{2} \mathrm{O}_{3}$ in the amorphous phase resulting in a biphasic structure for $\mathrm{T}_{\mathrm{d}}>600^{\circ} \mathrm{C}$.

\section{References.}

[1] R. Dupree, I. Farnan, A.J. Forty, S. El-Mashri, L. Bottyan, A MAS NMR study of the structure of amorphous alumina films, J. Phys. Colloques 46 (1985) C8 113-117.

[2] I. Farnan, R. Dupree, Y. Jeong, G.E. Thompson, G.C. Wood, A.J. Forty, Structural Chemistry of Anodic Alumina, Thin Solid Films 173 (1989) 209-213.

[3] I. Farnan, R. Dupree, A.J. Forty, Y.S. Jeong, G.E. Thompson, G.C. Wood, Structural information about amorphous anodic alumina from ${ }^{27}$ Al MAS NMR, Phil. Mag. Lett. 59 (1989) 189-195. 
[4] R.C.T. Slade, J.C. Southern, I.M. Thompson, 27Al Nuclear Magnetic Resonance Spectroscopy Investigation of Thermal Transformation Sequences of Alumina Hydrates. Part 1.- Gibbsite, gamma-Al(OH) $)_{3}$, J. Mater. Chem. 1 (1991) 563-568.

[5] R.H. Meinhold, R.C.T. Slade, R.H. Newman, High Field MAS NMR, with Simulations of the Effects of Disorder on Lineshape, Applied to Thermal Transformations of Aluminas Hydrates, Appl. Magn. Reson. 4 (1993) 121-140.

[6] F.R. Chen, J.G. Davis, J.J. Fripiat, Aluminum Coordination and Lewis Acidity in Transition Aluminas, J. Catal. 133 (1992) 263-278.

[7] G. Kunath-Fandrei, T.J. Bastow, J.S. Hall, C. Jäger, M.E. Smith, Quantification of Aluminum Coordinations in Amorphous Aluminas by Combined Central and Satellite Transition Magic Angle Spinning NMR Spectroscopy, J. Phys. Chem. C 99 (1995) 15138-15141

[8] J.H. Kwak, J.Z. Hu, D.H. Kim, J. Szanyi, C.H.F. Peden, Penta-coordinated $\mathrm{Al}^{3+}$ ions as preferential nucleation sites for $\mathrm{BaO}$ on gamma- $\mathrm{Al}_{2} \mathrm{O}_{3}$ : An ultra-high-magnetic field ${ }^{27} \mathrm{Al}$ MAS NMR study, J. Catalysis, 251 (2007) 189-194.

[9] J.H. Kwak, J. Hu, A. Lukaski, D.H. Kim, J. Szanyi, C.H.F. Peden, Role of Pentacoordinated $\mathrm{Al}^{3+}$ Ions in the High Temperature Phase Transformation of gamma- $\mathrm{Al}_{2} \mathrm{O}_{3}$, J. Phys. Chem. C 112 (2008) 9486-9492.

[10] C. Pecharroman, I. Sobrados, J.E. Iglesias, T. Gonzalez-Carreno, J. Sanz, Thermal Evolution of Transitional Aluminas by NMR and IR Spectroscopies, J. Phys. Chem. B 103 (1999) 61606170.

[11] S.K. Lee, S.B. Lee, S.Y. Park, Y.S. Yi, C.W. Ahn, Structure of amorphous aluminum oxide, Phys. Rev. Lett. 103 (2009) 095501.

[12] S.K. Lee, S.Y. Park, Y.S. Yi, J. Moon, Structure and Disorder in Amorphous Alumina Thin Films: Insights from High-Resolution Solid-State NMR, J. Phys. Chem. C 114 (2010) 1389013894.

[13] A.H. Tavakoli, M.P. Saradhi, S.J. Widgeon, J. Rufner, K.v. Benthem, S. Ushakov, S. Sen, A. Navrotsky, Amorphous Alumina Nanoparticles: Structure, Surface Energy, and Thermodynamic Phase Stability, J. Phys. Chem. C 117 (2013) 17123-17130.

[14] J.-P. Coutures, D. Massiot, C. Bessada, P. Echegut, J.-C. Rifflet, Etude par RMN 27Al d'aluminates liquides dans le domaine $1600-2100{ }^{\circ}$ C, C. R. Acad. Sci. Paris 310 (1990) 1041.

[15] D. Massiot, F. Taullele, J.-P. Coutures, Structural diagnostic of high-temperature liquid phase by aluminum-27 NMR, J. Phys. Coll. 51 (1990) 425-431.

[16] B.T. Poe, P.F. McMillan, B. Coté, D. Massiot, J.-P. Coutures, Silica-Alumina Liquids: In-Situ Study by High-Temperature ${ }^{27}$ Al NMR Spectroscopy and Molecular Dynamics Simulation, J. Phys. Chem. 96 (1992) 8220-8224.

[17] J.P. Coutures, J.C. Rifflet, P. Florian, D. Massiot, Etude par analyse thermique et par RMN très haute température de ${ }^{27} \mathrm{Al}$ de la solidification de $\mathrm{Al}_{2} \mathrm{O}_{3}$ en l'absence de nucléation hétérogène : effets de la température du liquide et de la pression partielle d'oxygène, Rev. Int. Hautes Tempér. Réfract. 29 (1994) 123-142.

[18] P. Florian, D. Massiot, B. Poe, I. Farnan, J.P. Coutures, A time resolved ${ }^{27}$ Al NMR study of the cooling process of liquid alumina from $2450^{\circ} \mathrm{C}$ to crystallization, Solid State Nucl. Magn. Reson. 5 (1995) 233-238.

[19] L.B. Skinner, A.C. Barnes, P.S. Salmon, L. Hennet, H.E. Fischer, C.J. Benmore, S. Kohara, J.K.R. Weber, A. Bytchkov, M.C. Wilding, J.B. Parise, T.O. Farmer, I. Pozdnyakova, S.K. Tumber, K. Ohara, Joint diffraction and modeling to the structure of liquid alumina, Phys. Rev. B 87 (2013) 024201. 
[20] V. Sarou-Kanian, A.N. Gleizes, P. Florian, D. Samélor, D. Massiot, C. Vahlas, TemperatureDependent 4-, 5- and 6-Fold Coordination of Aluminum in MOCVD-Grown Amorphous Alumina Films: A Very High Field ${ }^{27}$ Al-NMR Study, J. Phys. Chem. C 117 (2014) 2196521971.

[21] D. Samélor, M.M. Sovar, A. Stefanescu, A.N. Gleizes, P. Alphonse, C. Vahlas, Low temperature CVD route for the preparation of alumina coatings with a high specific surface area, in: H.P. A. Devi, M.L. Hitchman, R.A. Fischer, M.D. Allendorf (Ed.) 15th European Conference on Chemical Vapor Deposition (EuroCVD-15), Electrochemical Society Proceedings Volume 2005-09, 2005, pp. 1051-1058.

[22] D. Massiot, F. Fayon, M. Capron, I. King, S.L. Calvé, B. Alonso, J.O. Durand, B. Bujoli, Z. Gan, G. Hoatson, Modelling 1- and 2-dimensional solid-state NMR spectra, Magn. Reson. Chem. 40 (2002) 70-76.

[23] A.N. Gleizes, C. Vahlas, M.-M. Sovar, D. Samélor, M.-C. Lafont, CVD-Fabricated Aluminum Oxide Coatings from Aluminum tri-iso-propoxide: Correlation Between Processing Conditions and Composition, Chem. Vap. Deposition 13 (2007) 23-29.

[24] G. Czjzek, J. Fink, H. Schlmidt, J.M.D. Coey, J.P. Rebouillat, A. Lienard, Atomic coordination and the distribution of electric field gradients in amorphous solids, Phys. Rev. B 23 (1981) 2513-2530.

[25] G.L. Caër, R.A. Brand, General models for the distributions of electric field gradients in disordered solids, J. Phys: Cond. Mat. 10 (1998).

[26] J.-B.d.E.d. Lacaillerie, C. Frétigny, D. Massiot, MAS NMR spectra of quadrupolar nuclei in disordered solids: The Czjzek model, J. Magn. Reson. 192 (2008) 244-251.

[27] P. Florian, E. Véron, T. Green, J.R. Yates, D. Massiot, Elucidation of the Al/Si ordering in Gehlenite $\mathrm{Ca}_{2} \mathrm{Al}_{2} \mathrm{SiO}_{7}$ by combined ${ }^{29} \mathrm{Si}$ and ${ }^{27} \mathrm{Al} \mathrm{NMR}$ spectroscopy / quantum chemical calculations, Chem. Mater. 24 (2012) 4068-4079.

[28] P. Florian, N. Sadiki, D. Massiot, J.P. Coutures, ${ }^{27}$ Al NMR Study of the Structure of Lanthanum- and Yttrium-Based Aluminosilicate Glasses and Melts, J. Phys. Chem. B 111 (2007) 9747-9757.

[29] S. Iftekhar, B. Pahari, K. Okhotnikov, A. Jaworski, B. Stevensson, J. Grins, M. Edén, Properties and Structures of $\mathrm{RE}_{2} \mathrm{O}_{3}-\mathrm{Al}_{2} \mathrm{O}_{3}-\mathrm{SiO}_{2}(\mathrm{RE}=\mathrm{Y}, \mathrm{Lu})$ Glasses Probed by Molecular Dynamics Simulations and Solid-State NMR: The Roles of Aluminum and Rare-Earth Ions for Dictating the Microhardness, J. Phys. Chem. C 116 (2012) 18394-18406.

[30] Y. Balcaen, N. Radutoiu, J. Alexis, J.D. Beguin, L. Lacroix, D. Samélor, C. Vahlas, Mechanical and barrier poperties of MOCVD processed alumina coatings on Ti6A14V titanium alloy, Surf. Coat. Technol. 206 (2011) 1684-1690.

[31] Y. Kijima, T. Hanada, Effect of the pressure of sputtering atmosphere on the physical properties of amorphous aluminum oxide films, J. Mater. Sci. 35 (2000) 2193-2199.

[32] G. Alcala, P. Skeldon, G.E. Thompson, A.B. Mann, H. Habazaki, K. Shimizu, Mechanical properties of amorphous anodic alumina and tantala films using nanoindentation, Nanotechnology 13 (2002) 451-455.

[33] S. Nakao, P. Jin, D. Music, U. Helmersson, M. Ikeyama, Y. Miyagawa, S. Miyagawa, Influence of high-energy $\mathrm{Si}^{+}$ion irradiation on microstructure and mechanical properties of alumina films, Surf. Coat. Technol. 158-159 (2002) 534-537.

[34] J.C. Barbour, J.A. Knapp, D.M. Follstaedt, T.M. Mayer, K.G. Minor, D.L. Linam, The mechanical properties of alumina films formed by plasma deposition and by ion irradiation of sapphire, Nucl. Instr. and Meth. in Phys. Res. B 166-167 (2000) 140-147. 
[35] M. Natali, G. Carta, V. Rigato, G. Rossetto, G. Salmaso, P. Zanella, Chemical, morphological and nano-mechanical characterizations of $\mathrm{Al}_{2} \mathrm{O}_{3}$ thin films deposited by metal organic chemical vapour deposition on AISI 304 stainless steel, Electrochim. Acta 50 (2005) 46154620.

[36] D. Samélor, A.-M. Lazar, M. Aufray, C. Tendero, L. Lacroix, J.-D. Béguin, B. Caussat, H. Vergnes, J. Alexis, D. Poquillon, N. Pébère, A. Gleizes, C. Vahlas, Amorphous Alumina Coatings: Processing, Structure and Remarkable Barrier Properties, J. Nanosci. Nanotechnol. 11 (2011) 1-5.

[37] G. Boisier, M. Raciulete, D. Pébère, A.N. Gleizes, C. Vahlas, Electrochemical Behavior of Chemical Vapor Deposited Protective Aluminum Oxide Coatings on Ti6242 Titanium Alloy, Electrochem. Solid-State Lett. 11 (2008) C55-C57.

[38] A.-M. Lazar, W.P. Yespica, S. Marcelin, N. Pébère, D. Samélor, C. Tendero, C. Vahlas, Corrosion protection of 304L stainless steel by chemical vapor deposited alumina coatings, Corrosion Sci. 81 (2014) 125-131. 